\title{
Gordon C. Roadarmel 1932-1972
}

PROFESSOR GORDON C. ROADARMEL of the Department of South and Southeast Asian Languages and Literatures at the University of California, died in Berkeley on June 14, 1972. His death represents a grave loss to the cause of Indian literature in the English-speaking world.

Professor Roadarmel was born in $\mathbf{1 9 3 2}$ in India of missionary parents. After graduating from the Woodstock School, Mussoorie, he came to the United States to enter the College of Wooster in Ohio, where he received his B.A. in 1954. He took M.A. degrees in English and Asian Studies at the University of California, Berkeley, and his $\mathrm{Ph} . \mathrm{D}$. in Hindi literature in 1969 at the same institution, where he had been a member of the faculty and where, in 1966 , he was cited for distinguished teaching. From 1967 to 1968 Professor Roadarmel was Director of the Berkeley Professional Studies Program in New Delhi. In 1970 he was elected to the South Asia Regional Council of the Association for Asian Studies and served as a member of its Library and Documentation Committee. His other honors included membership in Phi Beta Kappa, a Woodrow Wilson Fellowship, a Fulbright research grant for the study of Hindi literature at the University of Allahabad, 1962-64, and a Carnegie Internship at the University of Chicago. At the time of his death he had just returned from a year in India, where he had concontinued his research and writing.

$\mathrm{He}$ was a pioneer in introducing modern Hindi literature to the Western world with his critical articles and his translations of such major figures as Premchand, Jainendra Kumar and Mohan Rakesh. His translation of Premchand's Godan has been produced in Braille, and his articles, reviews and translations of contemporary Hindi short stories and poetry have appeared widely in leading Indian and American journals. His Bibliography of English Source Materials for the Study of Modern Hindi Literature is an indispensable aid to research for students of modern Hindi letters. His volume of translations and interpretations of Hindi short stories will be published by the University of California Press in the fall of 1972 under the title $A$ Death in Delhi.

The most significant contribution Professor Roadarmel made was in his reviving of a truly humanistic approach to Indian literature at a time when the study of Asian languages had become in the narrowest sense pragmatic and tended to ignore entirely genuine literary values. Both his critical interpretations and his choice of works for translation showed his profound conviction that literature is important as a documenting of universal human nature and human problems and that Hindi literature, measured by these standards, can be ranked with the other great literatures of the twentieth century. The excellence of his translations, with their fidelity and integrity of style, effectively confirm this estimate.

This same humanism was a constant element in Gordon Roadarmel's personal associations. He had an uncommon empathy and concern for his colleagues, students and friends. His generosity and kindness affected many people. We will miss him at a time in his rich life when he was giving us all so much.

Walter Hauser

Warren F. Ilchman

David Rubin 